\title{
From Peasant to Elite: Reshaping Agriculture in Gansu Province
}

\section{René Trappel}

\section{(2) OpenEdition \\ 1 Journals}

\section{Electronic version}

URL: https://journals.openedition.org/chinaperspectives/11610

DOI: 10.4000/chinaperspectives. 11610

ISSN: 1996-4617

\section{Publisher}

Centre d'étude français sur la Chine contemporaine

\section{Printed version}

Date of publication: 1 June 2021

Number of pages: 9-18

ISSN: 2070-3449

\section{Electronic reference}

René Trappel, "From Peasant to Elite: Reshaping Agriculture in Gansu Province", China Perspectives [Online], 2021/2 | 2021, Online since 01 June 2021, connection on 17 November 2022. URL: http:// journals.openedition.org/chinaperspectives/11610 ; DOI: https://doi.org/10.4000/chinaperspectives. 11610

All rights reserved 


\title{
From Peasant to Elite: Reshaping Agriculture in Gansu Province
}

\author{
RENÉ TRAPPEL
}

\begin{abstract}
This article contributes to the growing body of research on the role of the Party-state in shaping an emerging post-peasant modernity in rural China, taking developments in Gansu Province as a case. The article first analyses how a political preference for an agrarian elite has been put into recent policies and translates into rural practices. It argues that the "new-type agricultural management subjects," which form the core of this elite, should also be considered as a policy instrument designed to promote structural change in Chinese agriculture. This article proceeds to explore the capacity of the new agrarian elite as local development agents in Gansu Province. It focuses in particular on the legitimation of this instrument and its consequences for the structure of agriculture.
\end{abstract}

KEYWORDS: peasants, elite, smallholding, policy instruments, agrarian change, displacement, Gansu Province.

A fter several weeks of conducting interviews with smallholders and entrepreneurial farmers in Gansu Province in September and October 2016, I encountered an agrarian entrepreneur producing goat meat - on the top of a mountain in the middle of nowhere. He had come to this remote location specifically because it met the requirements for a project application and was expected to attract substantial subsidies (of which little had materialised so far). The land on which his farm buildings stood was designated waste land, which allowed for cheap long-term investment. He had rented an additional ten $m u^{1}$ of farmland from the villagers. On the nudging of local officials, he had also started a cooperative with some of the locals, despite having doubts about its purpose. Summarising his approach to farming at one point, he said, "The future of farming looks good - if you orient yourself to the goals of the government."2 The interview encapsulated, like many before and after, how closely today's agrarian entrepreneurs in China are frequently tied to the Party-state and depend on its support. Yet, more importantly, it also exemplified that entrepreneurial agriculture is not just a goal of rural modernisation policies. Through links to the local economy created by land transfers, hiring, and the founding of cooperatives, agrarian entrepreneurs were quickly turning into one of the state's major tools to achieve structural change.

One of the most interesting debates about Chinese agriculture concerns its structure in the future. Some scholars have argued for the resilience of peasant farming, in which a group of distinct peasants would continue to tend rather small plots, and important sections of agriculture would remain outside of market-based relations (Huang 2011; van der Ploeg and Ye 2016). Yet, the latest official data shows a rapidly changing structure of agriculture in China, potentially in conflict with this perspective. Between the years 2000 and 2019, employment in the primary sector of the economy (which includes agriculture) shrank from 360.43 million, or $50 \%$ of the workforce, to 194.45 million, or $25.1 \%$ (National Bureau of Statistics of China 2020b: 106). Concurrently, the introduction of commercial farming entities has become possible through a quickly expanding market for land usage rights. In $2013,26 \%$ of all farmland had been transferred from rural households to other households or farming entities, up from 9\% in 2000 and 17.1\% in 2008 (Yan and Chen 2015: 374-5). In 2017 the rate already stood at 37\% (China Economic Reform Journal 2019: 245). While class differentiation and structural change could be expected in an emerging Chinese agrarian capitalism (Zhang 2015), the political and economic environment shaping this process in China clearly does not provide all actors in agriculture with the same opportunities and is potentially impacting the resilience of peasant farming (Andreas and Zhan 2016: 812). This article argues that the importance of the link between an activist Party-state and a new elite of agrarian producers may not have been sufficiently taken into account in previous studies on agrarian change in China (noteworthy exceptions include Yan and Chen 2015; Andreas and Zhan 2016; Gong and Zhang 2017) - especially since the Xi administration has launched a multitude of new rural development policies aiming to restructure agriculture. ${ }^{3}$

Three potentially conflicting objectives for agrarian development seem dominant in the current agenda of the Party-state. ${ }^{4}$ First, a group of professional farming operations, clearly demarcated by the Party-state as "new-type agricultural management subjects" (xinxing nongye jingying zhuti 新型農業經營主體), referred to henceforth as "new agricultural subjects"), should replace smallholders ${ }^{5}$ as primary producers in agriculture. Second, this agrarian elite is envisioned as a tool to revitalise

\footnotetext{
1. A mu is equivalent to 0.0667 hectare or $667 \mathrm{sqm}$.

2. Interview, Dingxi City, 7 October 2016.

3. In recent years a number of outstanding studies on the dynamics of agrarian change in China have been published. See, for example, Zhang and Donaldson (2008, 2010); Ong (2014); Zhang, Oya, and Ye (2015); Ye (2015); Sargeson (2016); Schneider (2016); Yep (2020).

4. For a detailed introduction to these policies, please refer to the next section of the article.

5. This article defines smallholders as small and low-tech farming operations with limited external capital that primarily rely on household labour. This definition includes but also goes beyond subsistence farming.
} 
villages and integrate smallholders. In the official language this is often referred to as the daidong (帶動, literally to "bring along") function of modern farming (see also Schneider 2017: 90) and is seen as essential to increase and stabilise rural incomes. Both objectives, however, imply that modernisation requires the disruption of long-standing social and economic structures in rural China. ${ }^{6}$ Third, at the same time local officials should avoid forced displacement and disenfranchisement of peasants under all circumstances.

Against this backdrop, the investigation pursued here is twofold. First, this article analyses how the political preference for an agrarian elite has entered into recent policies and translates into rural practices. Second, it explores the role of the new agrarian elite as local development hubs. The research interest here is whether and how their existence may help to prevent the displacement of smallholders in rural China. For these analytical tasks, this paper draws on governance analysis and treats new agricultural subjects as a policy instrument. Here "[a] public policy instrument constitutes a device that is both technical and social, that organises specific social relations between the state and those it is addressed to, according to the representations and meanings it carries" (Lascoumes and Le Galès 2007: 4). Instead of a functional perspective that deals with questions of effective or efficient implementation, the focus in this paper is placed on exploring the legitimation and the social consequences of the promotion of new agricultural subjects (see also Le Galès 2011).

This article draws on two rounds of fieldwork in Gansu Province (2016 and 2019), during which about 70 interviews with different groups of actors in rural China were conducted. Gansu Province was chosen because it is one of the western provinces in which the discrepancy between the vision of the state and the current structure of the rural population is most apparent. ${ }^{7}$ The interviews took place within the city-level jurisdictions of Lanzhou, Baiyin, Pingliang, Dingxi, Tianshui, and Zhangye. Among the interviewees were traditional smallholders running small farming operations without much external investment or coordination and their government-designated replacements, the new agricultural subjects. The interviewees also included resettled villagers, in order to find out how resettlement had affected their relationship to smallholding. Furthermore, interviews were conducted with officials at various levels of the administration, from village to city-level. ${ }^{8}$

Following this introduction, the policies of the Party-state are discussed in more detail. Particular attention is paid to the relationship of new agricultural subjects to the discourse of rural modernisation, to markets for farmland, and to the marketisation of agricultural goods. The next section takes an empirical look at the role of new agricultural subjects in the rural modernisation of Gansu Province. The focus of this case study is on how this new agrarian elite interacts with the Party-state and villagers.

\section{The politics of agrarian modernisation in China}

\section{Agrarian development and governance}

The modernisation of the countryside and especially of agriculture has been a central element of the Chinese Communist Party's (CCP) agenda since 1949. While the political understanding of rural modernity has changed considerably over the years (Unger 2002), the overall will of the communist Party-state to address its perceived lack has not. The angle taken in this analysis is that the Party-state has identified the current state of agriculture as a problem for public management (Hood
1998), and has created and employed a variety of policy instruments to address its alleged shortcomings. As noted above, instead of seeing changes in the selection of policy instruments as merely functional, this article argues that the choice of one instrument over another provides insights into the priorities of those that govern and their framing of the governed (Le Galès 2011). Different policy instruments are legitimised to the public in different ways. In other words, choosing a policy instrument or, more precisely, a specific mix of policy instruments, becomes a political decision. Given the nature of the Chinese political system, we have little insight into the processes that go into these decisions - but we have an excellent record of the framing of these decisions through government and party directives. The analysis in this section of the article will therefore explore the selection, contents, and legitimation of policy instruments in relation to specific groups in agriculture.

The first recent step toward structural reform of agriculture in China has been the so-called "Building the New Socialist Countryside" (shehuizhuyi xin nongcun jianshe 社會主義新農村建設), a massive framework for rural development by the previous $\mathrm{Hu} /$ Wen administration (Bray 2013; Ahlers 2014; Looney 2020). Retrospectively, however, this was only the starting point for a whole series of initiatives by the current administration. In 2014, the plan for "New-Type Urbanisation" (xinxing chengzhenhua 新型城鎮化) was unveiled (CCP Central Committee and State Council 2014). In 2015, Xi Jinping declared a "War on Poverty" (tuopin gongjianzhan 脱貧攻堅戰) to address the last pockets of rural poverty (CCP Central Committee and State Council 2015). The Document No. 1 in 2018 announced the policy of "Rural Revitalisation" (xiangcun zhenxing 鄉村振興) (CCP Central Committee and State Council 2018a), which is part of the larger efforts of the "Great Rejuvenation of the Chinese Nation" (Zhonghua minzu weida fuxing 中華民族偉大復興). In the same year, the "Plan for the Rural Revitalisation Strategy (2018-2022)" was announced (CCP Central Committee and State Council 2018b). In addition to these large frameworks, several lesser-known policies such as the "Plan for Agricultural Modernisation 2016-2020" (State Council 2016, "2016 Plan" henceforth) and even local policies such as the "Three Changes Reform" (sanbian gaige 三變改革) (Gansu Province CCP Party Committee and Gansu Province People's Government 2017) continue to add details to this agenda.

All of the above-mentioned policies link the danger of poverty and underdevelopment in the countryside to poor lifestyle choices, insufficient investment, and the lack of commodification of collective resources. Comparatively low levels of income and education, the absence of skilled workers, sub-standard housing, poor village appearance, and a gap in public services between village and city would be the consequence of these issues. ${ }^{9}$ The rural reform agenda centres on transforming these

6. The 2018 Document No. 1 puts it bluntly: "If there is no modernisation of agriculture and villages, there will be no modernisation of the nation" and "the Rural Revitalisation Strategy (...) is where the battle for the 'Moderately Prosperous Society' (xiaokang shehui 小康社會) and the historical task of building a modern socialist country will be decided" (CCP Central Committee and State Council 2018a). Documents No. 1 are special official statements on agriculture and the countryside, jointly published by the State Council and the Central Committee of the Chinese Communist Party. They are usually the first jointly published documents in a given year, hence the name.

7. The author is greatly indebted to Prof. Han Guoming and Ms. Guo Pengpeng at Lanzhou University.

8. In order to protect the privacy of interviewees, only the city-level jurisdiction and the date will be used to reference interviews. Several interviews took place on the same day.

9. The Rural Revitalisation Plan provides a good summary of these points (CCP Central Committee and State Council 2018b). 
very circumstances. Specifically, the plans urge the commercialisation of agriculture, the relocation of part of the rural population to urban centres (or, more precisely, to the fringes of these centres), and a transition of the workforce from agriculture to industry and services. Economic growth and the ability to raise the incomes of the rural population have become the primary yardsticks to measure the success of development efforts. One means to achieve this goal is to modernise agriculture through an increase in scale and the amount of invested capital through the spread of production and product standards and through technological change. Most significant, however, is the selection of a specific group of agrarian producers, the new agricultural subjects, as the state's local agrarian development partners. A vivid public and intellectual debate on alternative approaches to agrarian and rural development, pushed in particular by members of the so-called "New Rural Reconstruction" movement (xin xiangcun jianshe 新鄉村建設) such as Wen Tiejun and He Xuefeng, appears largely to be ignored (Day 2013; Day and Schneider 2017). With the exception of some local experiments, these alternative ideas and discourses do not figure prominently in local development plans or - as in the case of cooperatives - are sometimes even turned on their head (Yan and Chen 2013; Hu et al. 2017).

In order to achieve its goal of rural modernisation, the Party-state is thus pursuing a two-pronged strategy: first, a calibrated deconstruction of previous notions of peasant farming deemed inefficient, and second, the creation of a new entrepreneurial rural elite, framed as more likely to create economic growth, employment, and safe food in an internationally competitive way.

\section{Deconstructing peasants}

Through scientific, political, and public narratives, agriculture in China (and in the rural population in general) to this day is linked to the idea of "peasants" (nongmin 農民) (Schneider 2015; Sargeson 2016). In China, the term does not necessarily describe an occupation but is part of a "differential citizenship" (Wu 2010) that regulates access to the state, resources, and public services. ${ }^{10}$ The status is inherited upon birth from one's parents. Frequently this has also been referred to as the household registration system or hukou (戶口) system. Because of this institution, people officially classified as peasants in China do not necessarily work in agriculture, nor do they live only in the countryside (He 2016). The central policy guidelines frequently highlight the importance of protecting the "rights and interests" of the rural population, for which the term peasant is used. When speaking about peasant farming, however, newer documents now use the term smallholder (xiaonong 小農) and promote their integration into modern agrarian production networks (CCP Central Committee and State Council 2018a). The lack of a clear differentiation between peasants as producers and peasants as members of the rural population brings with it the need for the Party-state to carefully craft reform policies to align with political sensibilities.

Exploring official narratives, Mindi Schneider (2015) shows how the political and social discourse in China often frames peasants as backward, in need of help, and as surplus labour that could be of more use elsewhere (see also Kipnis 1995). All of these characterisations appear to be of particular importance when referring to smallholding. As one directive from 2015 states plainly: "Even with better use of technology, better provision of financial services, [and] better integration into the market, it would still be difficult [for small producers] to bring forward standardised production, to improve the quality of agricultural products, to increase production efficiency, and to increase market competitiveness" (Ministry of Agriculture and Rural Affairs, and Ministry of Finance 2015: section 1). In accordance with this logic, the Party-state pursues a deconstruction of the relationship between peasants and agriculture in order to develop agriculture.

The first step taken in this direction was to weaken the historic and political equation of peasants and the rural population in order to allow for the separation of agrarian production from the notion of a peasant class (Sargeson 2016). If farming becomes an occupation rather than a lifestyle or a class, removing the worst performing elements from that part of the economy becomes a valid strategy for rural modernisation. An emerging rural welfare state that included a rural health care insurance system, a pension scheme, poverty alleviation programmes including a minimum living allowance as well as resettlement housing programmes (on these reforms see Howell and Duckett 2019), and the continued existence of more profitable wage-earning employment, either in the cities or in the countryside, provided the material basis for this transition and created opportunities for a voluntary exit from smallholding (see also Chatterjee 2008 on the relationship between welfare state and agrarian change).

The second step of the deconstruction was loosening the link between rural hukou and usage of collective property rights (Andreas and Zhan 2016; Zhan 2017). In the reform era there have been many legal, semilegal (in line with the letter of the law but not with its spirit), or plainly illegal ways to separate peasants from collective land, primarily to gain new construction land (Hsing 2010; Ho 2005). In agriculture, however, collective ownership as a legacy of the socialist property system provided a formidable barrier against large-scale commercial takeover of farmland (Zhang and Donaldson 2013). For policy makers, this institution set unfortunate limits in regard to the transfer of collective resources from allegedly inefficient producers to more efficient ones, and numerous reforms have tried to provide workarounds. Most of these approaches centre on the concept of land transfer (tudi liuzhuan 土地流轉). This policy instrument allows for the creation of a market for farmland, a requirement for opening up agriculture to external investors.

Land transfer builds on the premise that collective land usage rights, which the rural population usually receive upon birth as part of a rural household registration, can be rented out for a profit. Because only usage rights but not ownership rights are transferred, this is still in line with collective ownership. Land transfer is actively promoted by central and local governments, who have created a multitude of mechanisms for this purpose (Ye 2015; Trappel 2016; Gong and Zhang 2017). One of the latest iterations is the so-called "Three Changes Reform," which originated in Guizhou Province (Gansu Province CCP Party Committee and Gansu Province People's Government 2017, "2017 Opinions" henceforth). ${ }^{11}$ In

10. It is surprisingly difficult to find numbers for those officially classified as peasants. A table in the "Plan for New-type Urbanisation" shows a 17.3\% gap between those living in the city and those actually having an urban household registration ( $52.6 \%$ and $35.3 \%$ respectively) for the year 2012 (CCP Central Committee and State Council 2014). In recent years, the National Bureau of Statistics of China prefers to differentiate between (long-term) urban residents and rural residents. In 2019, rural residents made up 39.4\%, down from 50.1\% in 2010 and $73.6 \%$ in 1990 (National Bureau of Statistics of China 2020a: 51).

11. This policy came on the heels of a recent reform aiming to further clarify property rights of collective land and to remove obstacles to their marketisation (General Office of the CCP Central Committee and the General Office of the State Council). The main line of this reform was the "separation of the three rights" (sanquan fenzhi 三權分置), i.e. the separation of ownership rights, contractual rights, and management rights. In many regards, the reform codified practices that had already been in place for several years (see also Trappel 2016). 
2019, this policy was implemented in several of my field sites and seemed to rapidly gain traction all over China. Due to its possible disruptive nature, the exemplary character for other reforms targeting agriculture and collective resources, and very few non-Chinese reports on its contents, a closer examination seems warranted. ${ }^{12}$

The reform has three main components. The first, turning idle collective resources into collective property rights, is expected to increase the value of these resources by allowing for an easier transfer to more profitable operators. The resources explicitly mentioned are farmland, forest land, waste land, wetlands, and even idle housing, as well as all means of production. These are to be examined, evaluated, and priced, i.e. to be commodified. Scope and process differ considerably from past approaches, which mostly excluded housing and provided only very limited guidelines on finding prices. The second component is the most unusual one. Direct state subsidies and transfer funding to support economic development or individual households (with the exception of direct budget support or social security payments) are to be pooled and invested in promising economic activities. The village collective and individual villagers in turn would receive shareholder rights, and profit would be distributed accordingly. Especially funding targeting designated destitute households (pinkun hu 貧困戶) (with the exceptions mentioned above) should be directed to business entities with better economic performance. The third and final component is to increase the income of villagers by turning them into shareholders who receive dividends from their property rights. The 2017 Opinions states that officials should encourage and guide villagers to voluntarily invest their property rights in farmland and construction land, infrastructure, machinery, capital, and technology, as well as investing skills, labour, and other intangible assets into shareholding operations.

The crucial aspect in all of these efforts is to strengthen the role of markets in the transfer of resources, and indeed, a key phrase in most recent policy documents on the development of agriculture - including the $14^{\text {th }}$ Five-year Plan - is to "fully allow for the decisive function of markets in the redistribution of resources" (CCP Central Committee 2020).

The third and final step of deconstructing peasants is the insistence of using markets not only as the primary mechanism to redistribute resources but also for produced goods. All recent policies highlight the importance of being competitive and resource-efficient in producing agrarian goods. Performance in national and global markets is seen as the main indicator to judge whether these goals have been achieved. Following Warren Samuels, this article understands existing markets (in contrast to markets in the abstract) as social constructs in which efficiency is "rights-structure dependent" (2004: 358), and manipulation attempts by powerful actors are always possible. In effect, markets do not have to be fair for all participants. The impact of marketisation in agriculture on the social structure of the Chinese countryside is therefore an important empirical question.

To summarise, according to the national policy framework, the deconstruction of peasants as the main form of organisation for agrarian production in China hinges on several critical steps. First, further decoupling of peasants and agriculture is seen as necessary. Second, the transfer of farmland and other collective resources via the market (even though limits on the transfer of ownership remain) with the goal of increasing capitalist productivity should be promoted. Third, the competitiveness of different agrarian producers, to be decided in markets, is the main factor in judging their value for the Chinese economy.

\section{Fostering elites}

The narrative of the Party-state is clear: new actors and allies in the countryside are required to push forward the national development agenda. The new agricultural subjects are a policy instrument not only to attract more investors to the countryside and to steer them into certain directions but also to incubate development hotspots that radiate into their rural surroundings. The 2018 Document No. 1, for example, explicitly urges everyone to pay attention to the daidong function of the new agricultural subjects (CCP Central Committee and State Council 2018a). Important sub-types are dragon head enterprises (longtou qiye 龍頭企 業), cooperatives (hezuoshe 合作社), family farms (jiating nongchang 家庭農場), and specialised households (zhuanye dahu, nongye dahu 專業大户，農業大戶) (see also Yan and Chen 2015: 367). The 2016 Plan expects producers of moderate scale, a category into which most new agricultural subjects fall, to make up $40 \%$ of all producers by 2020 - up from $30 \%$ in $2015 .^{13}$

Dragon head enterprises are commercial operations that have been either chosen or created by local governments to spearhead the development of larger commercial enterprises (Lingohr-Wolf 2011; Yan and Chen 2015; Schneider 2016). The 2021 Document No. 1 reiterates the importance of these enterprises for the modernisation of agriculture (CCP Central Committee and State Council 2021). Cooperatives in China differ considerably in design and operation from international practice. Their main purpose appears to be the organisation of collective resources for either production or transfer to other producers. Despite a public narrative and a legal framework that emphasises the participation of villagers in the creation and control of cooperatives, they are often the product of a cooperation between commercial producers and local governments. In fact, many appear to be primarily the result of local state interference, and their actual role for agriculture remains unclear (Yan and Chen 2015: 379; Hu et al. 2017; Kan 2019). Family farms are a more recent addition to commercial farming operations. While at least one element of their business is directly linked to agriculture, many family farms also operate in tourism or other parts of the service sector. Specialised households have existed since the early days of the reform era and fall into the category of professional farming operations while not legally qualifying as companies. All subtypes of the new agricultural subjects are politically seen as agents of rural modernisation and as the correct receiving end in the transfer of land usage rights. They should nurture a modern agriculture that is centred on profitable products and attractive salaries. Accordingly, every recent policy document up to the latest 2021 Document No. 1 pledges political and financial support to these producers (CCP Central Committee and State Council 2021). Yan Hairong and Chen Yiyuan see in the "official embrace of 'new subjects' of agriculture (...) a high-profile signal of the intensifying de-peasantisation tendency in the Chinese government's agrarian policy today" (2015: 388).

Other policy instruments have been brought into line with the new prioritisation of the agrarian elite. In 2015, China began a massive overhaul of its agricultural subsidies, starting with the "Guiding Opinions on Adjusting and Improving the Three Agricultural Subsidy Policies" (Ministry of Agriculture and Rural Affairs, and Ministry of Finance 2015,

12. If not noted otherwise, the following description is based on the 2017 Opinions.

13. See Table 1, "'Thirteenth Five-year Plan,' Key Indicators for Agricultural Modernization" ("Shisanwu" nongye xiandaihua zhuyao zhibiao "十三五" 農業現代化主要指標) (State Council 2016). 
referred henceforth as "2015 Opinions"). Frustration with an allegedly growing mismatch between the intention behind the system for agrarian subsidies first introduced in 2004 and subsequent developments in agriculture resulted in suggestions for a set of trial changes in five provinces, and national implementation started in 2016. The reforms were sparked by the perception of two primary issues. First, production costs in agriculture remained relatively high, and the effectiveness of the subsidies was low. Secondly, agricultural subsidies had become a means of direct income support for low-efficiency producers, while large producers had difficulty gaining any additional subsidies. The 2015 Opinions proposed the following changes: $80 \%$ of the subsidies would go to all producers maintaining farmland in active cultivation. The remaining $20 \%$, however, would only go to larger producers, e.g. the new agricultural subjects. Furthermore, those not actively cultivating their land, or using it for other kinds of agricultural production (including livestock farming), would not be eligible for any subsidies from the first pool. ${ }^{14}$

Summarising the above, the new agricultural subjects are an essential ingredient of the rural development strategy of the Party-state. Ideally, this instrument links up to the market for collective farmland, provides templates for investors and creates employment and other economic opportunities for rural communities. Other instruments to modernise agriculture, such as the subsidy system, are designed to specifically support new agricultural subjects.

\section{Elite-driven agrarian development in Gansu Province}

This section first analyses how the actions of the Party-state have affected the prospects of different farming operations in our field sites in Gansu Province, before exploring the link between new agricultural subjects and other producers in greater depth. Gansu is one of the western provinces that still lags behind the economic development of the coastal provinces. The province currently tries to take advantage of the "Belt and Road Initiative," an attempt to revitalise the notion of the historic Silk Road. ${ }^{15}$ Lanzhou, the provincial capital, and the prefectural cities close by, where the research for this article was conducted, were centres for heavy industry and mining until very recently (in particular Lanzhou and Baiyin). These cities are now in the midst of structural economic change. Despite Gansu's mountainous and arid landscape, a substantial part of the rural population still engages in agriculture.

\section{Peasants and markets}

What are the effects of promoting the use of markets as a coordinating mechanism for agriculture, given the potential influence of the Partystate itself on the market positions of the various participants in these markets? In our fieldwork, different patterns of influence emerged: effects related to resettlements, to further commodification of collective resources, and to unequal treatment in government support.

In the tradition of previous approaches to rural modernisation and poverty alleviation, the central government continues to use resettlement as a key instrument in improving rural living conditions. Especially isolated villages with few valuable resources and difficult economic prospects have become a major target for these efforts. Villages close to (or even within) urban centres are a second major target. In our interviews, three different groups of resettled villagers emerged in terms of their relationship to farming. The first group were those who lost access to all of their collective farmland (see also Ong 2014; Yep 2020). The next group still had land usage rights but decided to transfer them to a third party. A subset of this group in our field sites had joined a reforestation project (tuigeng huanlin 退耕還林), which also provided them with another source of income but made a return to agriculture almost impossible. The third group was made up of those who continued to use part or all of their remaining land usage rights. In one village, a Party secretary noted that many villagers would still cultivate the land, even though they each only had a "few fen ${ }^{16}$ of land left." ${ }^{17}$ The average age of members of this third group was well above 50 years old. ${ }^{18}$ Resettlement and the distance to their fields affected the will of many villagers to transfer their land usage rights to entrepreneurial farmers, if they had any say in the process (if their hukou was changed, this was usually not the case).

Another influence was that of national and local efforts to speed up the commodification of collective resources to allow for the entry of external capital into the countryside. Here the Three Changes Reform again will serve as an example. Local newspapers from our field sites were enthusiastically reporting on the huge impact of this reform - especially for designated destitute households. ${ }^{19}$ A Party secretary described its practice in the following way:

In Six Pillars Village, the Three Changes Reform was like this: the village Party branch and the village committee took the lead and set up a membership-based agricultural cooperative. Afterwards they invited an agricultural development company from Zhangye City to invest in the shareholding. The village contributed land and [the expenses for] roads to the shareholding. Designated destitute households contribute their poverty aid to the shareholding, the company adds $50 \%$ [of the investment beyond these transfer funds], the village collective $20 \%$, and the villagers another $30 \%$. Currently they are setting up a "Gobi Desert Agricultural Project," and the proceeds of this project will be distributed to the villagers, who can also work at this agricultural base. In the last year, old folks who were unable to work elsewhere... they all worked here and each had an income of more than 10,000 RMB per year $(\ldots)^{20}$

In another village, the village committee was planning to use this approach to turn idle villager housing into the basis for rural home-

14. One article about the reform suggests that farming enterprises meeting a certain threshold in size (in most provinces $50 \mathrm{mu}$, in Guangdong $100 \mathrm{mu}$ ) would receive an additional subsidy of 100-230 RMB per mu of cultivated land. This would cover a substantial amount of the annual rental fee for farmland, which in our interviews had been in the range of 300-900 RMB per mu. See: “農民好消息: 2020年3項補貼將發, 家家上千元, 直接到卡!” (Nongmin hao xiaoxi: 2020 nian san xiang butie jiangfa, jiajia shang qian yuan, zhijie dao ka!, Good News for Peasants: In 2020, The 3 Subsidies [Programme] Will Be Introduced, [Providing] More Than a 1000 RMB to Every Family, Directly on their Card!), Tencent News, 5 May 2020, https://new.qq.com/ omn/20200505/20200505AOLNVK00.html (accessed on 20 July 2020).

15. Lin Xu, "Vision China Puts Spotlight on Yellow River Civilization and Gansu," China Daily, 25 September 2020, https://www.chinadaily.com.cn/a/202009/25/ WS5f6dc871a31024ad0ba7bee0.html (accessed on 12 November 2020)

16. A fen is a tenth of a mu or $66 \mathrm{sqm}$.

17. Interview, Zhangye, 19 March 2019

18. On the issue of age in the field sites, see also: Wang Yi, "'果"斷前行" ("Guo" duan qianxing, "Fruit [Farming]" Breaks Free [and] Moves Forward), Pingliang ribao (平涼日報), 11 November 2019, http://szb.plxww.com/epaper/plrb/20191111/articel02007a.htm (accessed on 26 August 2020).

19. “甘肅定西市: “三變改革激活農村產業發展新要素” (Gansu Dingxishi: “sanbian” gaige jihuo nongcun chanye fazhan xin yaosu, Dingxi City, Gansu Province: Three Changes Reform Activates New Factors in Rural Industrial Development), Gansu jingji ribao (甘肅經濟日報), November 2018, http://nc.mofcom.gov.cn/article/nyyw/201811/965628.html (accessed on 26 August 2020).

20. Interview, Zhangye, 20 March 2019. 
stay tourism. ${ }^{21}$ In one urban village (without any farmland left) the reform was mentioned as a useful tool that helped in creating a property management company, an employment agency, and a tourism company. ${ }^{22}$

Finally, in one critical regard, it was the absence of action by the Partystate that also had a great impact on the producers we met. In our interviews, the two primary complaints were the fluctuation in prices for agricultural products and the difficulty in acquiring additional funding. ${ }^{23}$ In fact, no single issue seemed more pressing than the need for more funding. Several small- and medium-sized producers suggested that the problem was not only with the interest rates on formal loans, which hovered at $7 \%$ to $8 \%,{ }^{24}$ but also with the difficulty of acquiring loans in the first place. ${ }^{25} \mathrm{~A}$ village head (and former village teacher) pointed out that ordinary smallholders above the age of 60 would have no chance getting a formal loan. ${ }^{26}$ Many of our interviewees had to rely on family and friends. ${ }^{27}$ While a small group had been able to get start-up grants through the local government (with low or no interest rates at all), those loans were not sufficient to meet their needs. ${ }^{28}$ Several stated that they would like to invest and expand their business but lacked the means to do so. $^{29}$ Even the central government pointed to these shortcomings in agrarian funding in the 2020 Document No. 1 (CCP Central Committee and State Council 2020).

The other major issue for producers has been fluctuating prices for their products. Producers of certain vegetables (e.g. tomatoes) and mushrooms, for example, complained about declining prices due to growing competition. ${ }^{30}$ Similar issues existed for livestock farming. One small producer of pork mused that, given the current low price for pork (in 2016), only the income from his store would keep him afloat. ${ }^{31}$ Government securities and insurance appear to be available only for larger producers. The 2020 Document No. 1 outlines the use of subsidies and an insurance system to stabilise the income of agricultural producers, suggesting that this is indeed a major issue (CCP Central Committee and State Council 2020: section 3, article 14).

Markets turned out to be crucial in legitimising structural change in our field sites. Our interviewees perceived the failure to succeed on the market mostly as a personal issue, not part of a structural shortcoming (see also Andreas and Zhan 2016: 809). Given the prevalence of higher-paying and less exhausting jobs, most current smallholders were pessimistic about the future of their farms after retirement. There was also little blame brought forward against the Party-state when smallholders decided to end independent production. For example, when asked about her dreams for the future, one resettled smallholder, in a sentiment shared by several others (resettled or not), said:

I want my children to be good at school, so that they can enter a good university (...) Farm work is hard, working in an office is more comfortable. (...) I don't want my children to come back [and work here]. ${ }^{32}$

The structure of the markets therefore may contribute to indirect displacement, which "occur[s] not when people are physically forced to move but rather when development planning and policies undermine or constrain livelihoods to the degree that people decide to move, seemingly of their own free will" (Vandergeest 2003: 47). A continued gradual disappearance of people from agriculture and the countryside is expected by the Party-state. The "Plan for New-type Urbanisation" and the "Plan for the Rural Revitalisation Strategy," for example, both contain sections covering the resettlement of the "agricultural transfer population" (nongye zhuanyi renkou 農業轉移人口).

\section{From peasants to elite}

The above listed factors affecting smallholders are setting the stage for the new agricultural subjects, the key policy instrument of the Chinese agrarian development strategy. Setting up such an organisation requires an application and meeting certain standards, mostly in regard to the scale of operations and funding. Receiving the status is usually rewarded with a subsidy and other types of support. The status of a family farm, for example, allegedly came with a 10,000 RMB subsidy. ${ }^{33}$ The impact of the new status on business strategies, however, was not clear, as most interviewees did not mention any change in their operations.

During fieldwork, certain patterns in the composition of these new agrarian elites became discernible. Most of the smaller specialised households encountered were former smallholders that had gradually been diversifying into commercial farming. Some had hired temporary workers, especially during harvest season, but most work was still done by family members. The average age in this group was well above 50 years. In larger operations, the personal situation and experience of the investor, usually male, for example as a retired member of the military, successful return migrant, or businessman with rural roots, has had an outsized role on the decision to engage in agriculture and on how operations were run. Among the new agricultural subjects, cooperatives and dragon heads hold special roles. Most cooperatives appear to have been set up primarily to improve the relationship with the local government or to help entrepreneurs structure their own business, and did not come with substantial subsidies. ${ }^{34}$ Dragon heads, in turn, appear to be much more directly tied to local governments than to all other types of new agricultural subjects (see below).

The status of a new agricultural subject seemed helpful to establish a link to the local government, which was mentioned by several interviewees ${ }^{35}$ as an important strategy for the well-being of their enterprise. ${ }^{36}$ One entrepreneur, for example, described how, in the process

21. Interview, Lanzhou, 15 March 2019

22. Interview, Dingxi, 27 March 2019.

23. Even members of the new agricultural subjects frequently mentioned their funding difficulties

24. One interviewee cited an interest rate of $12 \%$ for private loans (interview, Tianshui, 10 October 2016).

25. Interview, Tianshui, 11 October 2016

26. Interview, Baiyin, 6 October 2016.

27. The difference in funding has also been widely discussed in the media. A newspaper article mentions that in $2017,14.87 \%$ of regular farming households had been able to obtain a loan in the last three years. In contrast, the numbers were $17.34 \%$ for family farms and specialised households, 31.62\% for cooperatives, and 40.71\% for dragon head enterprises. See: "經濟日報調 查報告: 新型農業經營主體信貸規模有所提升" (Vingji ribao diaocha baogao: xinxing nongye jingying zhuti xindai guimo you suo tisheng, Investigation of Economic Daily: Scale of Credits for New-type Farming Subjects has Increased to Some Extend), Pengpai xinwen (澎湃新聞), 30 November 2019, https://www.thepaper.cn/newsDetail_forward_5105552 (accessed on 18 May 2020).

28. Interview, Tianshui, 10 October 2016

29. For example: interviews, Baiyin, 6 October 2016, and Tianshui, 10 October 2016

30. Interview, Lanzhou, 3 October 2016.

31. Interview, Baiyin, 6 October 2016; see also Sargeson (2016: 11); Schneider (2017: 95).

32. Interview, Dingxi, 26 March 2019.

33. Interview, Tianshui, 11 October 2016.

34. Tax regulations may also be a reason to form a cooperative. One head of a cooperative, for example, stated that "companies have to pay taxes, cooperatives do not." (Interview, Baiyin, 6 October 2016)

35. Party membership or having friends and relatives in the local government were also mentioned as important factors in getting timely access to information about subsidies and project-based funding

36. Interviews, Dingxi, 7 October 2016, and Tianshui, 10 October 2016 
of setting up livestock farming, he had established a close relationship with the local government and was even gifting high-quality pork to cadres to maintain good relations. He insisted on the importance of doing so for pork farming and acquiring subsidies. ${ }^{37}$ Those without Party membership or connections to the local government saw themselves at a disadvantage. ${ }^{38}$ Compared to small- and medium-sized producers, a striking difference in treatment became apparent during an interview with the manager of a dragon head company. ${ }^{39}$ He stated that the company received sufficient and annually increasing loans organised by the local government. He also mentioned help from all levels of the local government in finding cheap land well below market prices, in resettling the company, and in regard to other issues. According to him, support had even further increased after a recent visit by the Party secretary of Gansu Province.

One of the most interesting narratives surrounding new agricultural subjects is the idea that agrarian entrepreneurs are envisioned to daidong or "bring along" smallholders, agriculture, and the countryside as a whole to modernity. In the field sites, the importance of the concept became apparent in relation to the integration of smallholders as workers and the integration of their agrarian production.

Processes of agrarian differentiation and vertical integration have been described before (See, for example: Zhang and Donaldson (2008, 2010); Zhang (2015)). Similar trends were also on display in the field sites in Gansu. However, due to the rising number of external investors with little direct experience in farming, the number of wage-earning agrarian specialists and workers was also rising quickly. The specialists, who sometimes had been running their own farm previously, were hired on a long-term basis, and their salaries, which ranged from 18,000 RMB per year up to 150,000 RMB per year - depending on qualifications, skills and experience - reflected the growing demand. Several entrepreneurs mentioned that the lack of specialists has had an impact on their business. Most locals, however, were hired as temporary workers, earning between 50-80 RMB per day for female workers and 80-110 RMB per day for their male counterparts.

The integration of smaller farming operations to produce on behalf of commercial enterprises, in varying forms of dependence, was widespread in the field sites. The use of cooperatives to set up such variants of vertical integration appears to be an interesting recent addition to instances documented in the existing literature. In one case, the director of a dragon head enterprise used cooperatives to ensure product quality and to optimise production structures in the villages, urging the best local producers to lead the cooperatives. ${ }^{40}$ These cooperatives were clearly set up and run as an extension of his business and he referred to this as the "company + cooperative + household" development model. ${ }^{41}$ Another example of this variant was the combination of cooperative and company run by an entrepreneurial couple. Their company specialised in potato seedling production and had rented more than 3,000 mu of farmland for this endeavour. ${ }^{42}$ The cooperative provided villagers with training on how to produce seedlings. If they decided to engage in this form of production, they could start to work for the company, and almost all local villagers did so. The cooperative was run in a top-down manner, with little input by the villagers. ${ }^{43}$

Another variant of integration appeared to be based on an improvised franchise system. One case of this type was an entrepreneur specialising in apples, which was one of the main cash crops produced in this region of Gansu Province. He had leased out a number of his trees to other households for a fee. This income went into renting additional farmland to plant even more trees. ${ }^{44}$ According to him, $5 \mathrm{mu}$ of apple trees were enough for a comfortable life, and there would be "no need for labour migration anymore." 45

Daidong in the variants experienced during fieldwork was mostly based on a trade-in of smallholders' entrepreneurial independence for stable and higher incomes (see also McMichael 2013). In some cases, this may have helped to prevent displacement of villagers, as these higher incomes allowed them to stay in the countryside. The current political strategy mentioned in the $14^{\text {th }}$ Five-year Plan and the 2021 Document No. 1 to promote a diversification of the rural economy and the development of all three sectors of the economy (and not just agriculture) points to a similar strategy to prevent displacement (CCP Central Committee 2020; CCP Central Committee and State Council 2021).

\section{Conclusion}

Despite global calls for a re-peasantisation (van der Ploeg 2010; Hisano et al. 2018) and discussions surrounding the sustainability of industrial agriculture (Moore 2011; Schneider 2017), the Chinese Party-state is pushing for standardised, high-tech, high-investment medium-sized to large operations as the main form of agricultural production. To achieve this vision, it is promoting a new agrarian elite - not only as an ideal for agrarian production but also as a mechanism to transform agriculture. This article has looked at the increasingly important role of new agricultural subjects for Chinese agriculture through the prism of governance, treating them as a policy instrument.

Drawing on secondary literature as well as on Chinese policy documents, this article first explored how the Chinese state perceives, addresses, and communicates the need for structural change in agriculture. Specifically, it shows how smallholder farming in official directives is linked to perceived shortcomings in economic growth and difficulties in raising rural incomes. In order to move towards allegedly more efficient structures in agriculture, the Party-state is trying to separate the rural population from the notion of smallholding, to create markets for collective resources (including farmland) for external investors, and to establish competitive markets for agricultural goods as the main indicator for economic relevance.

The second part of this article analysed how this vision and the accompanying policies relate to rural practice in Gansu Province. Here the respective influence of the structure of markets and the efforts of local governments becomes clearer. For example, the various mechanisms to transfer land usage rights and the constant stream of new such tools this article discussed in detail the workings of the Three Changes Reform in Gansu Province - facilitate the transition from smallholding to the new

37. Interview, Baiyin, 6 October 2016

38. Interviews, Pingliang, 29 September 2016, and Dingxi, 5 October 2016

39. Interview, Tianshui, 11 October 2016

40. Interview, Tianshui, 11 October 2016

41. Local newspapers list many more different variants of these development models that integrate farming households in value chains (see, for example: Wang Yi, “果"斷前行” (“Guo" duan gianxing), op. cit.

42. Due to the large number of local smallholders leaving farming, renting land was not a big issue for them. The prices mentioned were much lower than in other regions, with $300 \mathrm{RMB}$ per $\mathrm{mu}$ per year for good farmland and $100 \mathrm{RMB}$ per mu per year for farmland with sub-par quality.

43. Interview, Baiyin, 6 October 2016.

44. In part, this was also related to his difficulty in getting a loan.

45. Interview, Pingliang, 29 September 2016. 
agricultural subjects. Local resettlement schemes contributed to the will of smallholders to end farming and to transfer their land usage rights. However, the two biggest push factors to leave independent agriculture were the volatility of prices and the difficulty in acquiring funding, which in particular affected smaller producers. In this context, the effort by local governments to use new agricultural subjects to daidong or "bring along" smallholders into the modern agriculture was of great importance. The integration of villagers' labour or their entire farming operations into the business of entrepreneurs contributes to the deconstruction of peasant farming.

In regard to the nexus of state, markets, and displacement, this article makes two important observations. First, through its interventions, the Party-state has created a tilted playing field for entrepreneurial farming in China. The general acceptance of markets as coordinating mechanism appears to legitimise efforts to restructure agriculture. Efficiency and competitiveness, however, are defined politically. There is a certain irony in the fact that the new agricultural subjects, which in the vision of the Party-state should help push rural China into a new era of modern agrarian production, are dependent on political and financial support to a greater degree than the smallholders they are meant to replace. The second observation is in regard to displacement. The new agrarian elite is expected to prevent physical displacement of smallholders to some degree by providing them with links to modern agriculture. Nonetheless, the integration of smaller producers and an emerging welfare state in the countryside cannot mask the transformational roots of Chinese agrarian development politics. While the Party-state urges everyone to respect the rights and interests of peasants, used here synonymously for the rural population, when it comes to the right to participate in economic growth, the conditions are set by the agenda of the Party-state. The empirical findings presented here are from Gansu Province only, but most policies presented are national, and earlier fieldwork in other provinces as well as secondary literature suggests that the trends described here may be taking place throughout China. The future of Chinese agriculture is on track for further elite-based development.

\section{Acknowledgements}

The author would like to thank the two anonymous reviewers and the editorial committee at China Perspectives for their insightful comments and helpful suggestions on earlier versions of the paper.

I René Trappel is a comparative political scientist and Senior Lecturer at the Institute of Chinese Studies at the University of Freiburg. His current research focuses on agrarian change, urbanisation, local governance, and state-society relations in China. Institute of Chinese Studies, University of Freiburg, Freiburg, Germany (rene.trappel@ sinologie.uni-freiburg.de).

Manuscript submitted on 7 October 2020. Accepted on 14 April 2021.

\section{References}

AHLERS, Anna L. 2014. Rural Policy Implementation in Contemporary China: New Socialist Countryside. London: Routledge.

ANDREAS, Joel, and Shaohua ZHAN. 2016. "Hukou and Land: Market Reform and Rural Displacement in China." The Journal of Peasant Studies 43(4): 798-827.

BRAY, David. 2013. "Urban Planning Goes Rural: Conceptualising the 'New village'." China Perspectives 95: 53-62.

CCP Central Committee 中國共產黨中央委員會. 2020. “中共中央 關於製定國民經濟和社會發展第十四個五年規劃和二零三五年 遠景目標的建議” (Zhonggong zhongyang guanyu zhiding guomin jingji he shehui fazhan di shisi ge wunian guihua he erlingsanwu nian yuanjing mubiao de jianyi, Suggestions of the CCP Central Committee on Drafting the $14^{\text {th }}$ Five-year Plan for National Economic and Social Development and the Long-term Goals for the Year 2035).

CCP Central Committee and State Council 中國共產黨中央委員會國 務院. 2014. “國家新型城鎮化規劃 (2014-2020年)” (Guojia xinxing chengzhenhua guihua (2014-2020 nian), National Plan for New-Type Urbanisation (2014-2020)).

. 2015. “中共中央國務院關於打贏脱貧攻堅戰的決 定” (Zhonggong zhongyang guowuyuan guanyu daying tuopin gongjianzhan de jueding, Decision of the CCP Central Committee and the State Council on Winning the War Against Poverty).

\section{—. 2018a. “中共中央國務院關於實施鄉村振興戰略的意} 見" (Zhonggong zhongyang guowuyuan guanyu shishi xiangcun zhenxing zhanlve de yijian, Opinions of the CCP Central Committee and the State Council on the Implementation of the Strategy of Rural Revitalisation).

. 2018b. “鄉村振興戰略規劃 (2018-2022年)” (Xiangcun zhenxing zhanlve guihua (2018-2022 nian), Plan for the Rural Revitalisation Strategy (2018-2022)).

. 2020. “中共中央國務院關於抓好'三農'領域重點工作確 保如期實現全面小康的意見” (Zhonggong zhongyang guowuyuan guanyu zhuahao "sannong" lingyu zhongdian gongzuo quebao ruqi shixian quanmian xiaokang de yijian, Opinions of the CCP Central Committee and the State Council on Grasping the Key Work in the Field of the "Three Rural Issues," Ensuring an On-schedule Realisation of an All-around Well-off Society).

2021. “中共中央國務院關於全面推進鄉村振興加快 農業農村現代化的意見” (Zhonggong zhongyang guowuyuan guanyu quanmian tuijin xiangcun zhenxing jiakuai nongye nongcun xiandaihua de yijian, Opinions of the CCP Central Committee and the State Council on Comprehensively Promoting Rural Revitalisation and Accelerating the Modernisation of Agriculture and the Countryside).

CHATTERJEE, Partha. 2008. "Peasant Cultures of the Twenty First Century." Inter-Asia Cultural Studies 9(1): 116-26. 
DAY, Alexander F. 2013. The Peasant in Postsocialist China: History, Politics, and Capitalism. Cambridge: Cambridge University Press.

DAY, Alexander F., and Mindi SCHNEIDER. 2017. "The End of Alternatives? Capitalist Transformation, Rural Activism and the Politics of Possibility in China." The Journal of Peasant Studies 45(7): 1221-46.

Gansu Province CCP Party Committee and the People's Government of Gansu Province 中國共產黨甘肅省委甘肅省人民政府. 2017. “中共甘肅省委甘肅省人民政府關於推進農村資源變資產資金 變股金農民變股東改革的指導意見” (Zhonggong Gansu shengwei Gansusheng renmin zhengfu guanyu tuijin nongcun ziyuan bian zichan zijin bian gujin nongmin bian gudong gaige de zhidao yijian, Guiding Opinions of the Gansu Provincial Party Committee and the People's Government of Gansu Province on Promoting the Reform of [Turning] Rural Resources Into Assets, [Transferring] Funding Into Capital, and Peasants Into Shareholders).

General Office of the CCP Central Committee and the General Office of the State Council 中國共產黨中央辦公室與國務院辦公室. 2016. “中共中央辦公室, 國務院辦公室關於完善農村土地所有權承包 權經營權分置辦法的意見” (Zhonggong zhongyang bangongshi, guowuyuan bangongshi guanyu wanshan nongcun tudi suoyouquan chengbaoquan jingyingquan fenzhi banfa de yijian, Opinions by the General Office of the CCP Central Committee and the General Office of the State Council on Improving the Method of Separating Rural Land Ownership, Contracting Rights and Management Rights).

GONG, Weigang, and Qian Forrest ZHANG. 2017. "Betting on the Big: State-Brokered Land Transfers, Large-Scale Agricultural Producers, and Rural Policy Implementation." The China Journal 77: 1-26.

HE, Xuefeng 賀雪峰. 2016. 誰是農民: 三農政策重點與中國現代 農業發展道路選舉 (Shei shi nongmin: sannong zhengce zhongdian yu Zhongguo xiandai nongye fazhan daolu xuanju, Who is a Peasant? Key Points of the Three Rural Policy and Critical Junctures in the Modernisation of Chinese Agriculture). Beijing: China Citic Press.

HISANO, Shuji, Motoki AKITSU, and Steven R. MCGREEVY. 2018 "Revitalising Rurality Under the Neoliberal Transformation of Agriculture: Experiences of Re-Agrarianisation in Japan." Journal of Rural Studies 61: 290-301.

HO, Peter. 2005. Institutions in Transition: Land Ownership, Property Rights, and Social Conflict in China. Oxford: Oxford University Press.

HOOD, Christopher. 1998. The Art of the State: Culture, Rhetoric and Public Management. Oxford: Clarendon Press.

HOWELL, Jude, and Jane DUCKETT. 2019. "Reassessing the Hu-Wen Era: A Golden Age or Lost Decade for Social Policy in China." The China Quarterly 237: 1-14.

HSING, You-tien. 2010. The Great Urban Transformation: Politics of Land and Property in China. Oxford: Oxford University Press.

HU, Zhanping, Qian Forrest ZHANG, and John A. DONALDSON. 2017. "Farmers Cooperatives in China: A Typology of Fraud and Failure." The China Journal 78: 1-24.
HUANG, Philip C. C. 2011. "China's New-Age Small Farms and Their Vertical Integration: Agribusiness or Co-ops?" Modern China 37(2): 107-34.

KAN, Karita. 2019. "A Weapon of the Weak? Shareholding, Property Rights and Villager Empowerment in China." The China Quarterly 237: 131-52.

KIPNIS, Andrew B. 1995. "Within and Against Peasantness: Backwardness and Filiality in Rural China." Comparative Studies in Society and History 37(1): 110-35.

LASCOUMES, Pierre, and Patrick LE GALÈS. 2007. "Introduction: Understanding Public Policy through its Instruments - From the Nature of Instruments to the Sociology of Public Policy Instrumentation." Governance 20(1): 1-21.

LE GALÈS, Patrick. 2011. "Policy Instruments and Governance." In Mark BEVIR (ed.), The Sage Handbook of Governance. Thousand Oaks: Sage. 142-59.

LINGOHR-WOLF, Susanne. 2011. Industrialisation and Rural Livelihoods in China: Agricultural Processing in Sichuan. London: Routledge.

LOONEY, Kristen E. 2020. Mobilizing for Development. Ithaca: Cornell University Press.

MCMICHAEL, Philip. 2013. "Value-chain Agriculture and Debt Relations: Contradictory Outcomes." Third World Quarterly 34(4): 67190.

Ministry of Agriculture and Rural Affairs, and Ministry of Finance 中華 人民共和國農業農村部與中華人民共和國財政部. 2015. “關於調 整完善農業三項補貼政策的指導意見” (Guanyu tiaozheng wanshan nongye sanxiang butie zhengce de zhidao yijian, Guiding Opinions on Adjusting and Improving the Three Agricultural Subsidy Policies).

MOORE, Jason W. 2011. "Transcending the Metabolic Rift: A Theory of Crises in the Capitalist World-Ecology." Journal of Peasant Studies 38(1): 1-46.

National Bureau of Statistics of China 國家統計局. 2020a. 中國住戶 調查主要數據 (Zhongguo zhuhu diaocha zhuyao shuju, Main Data of the Chinese Household Survey). Beijing: China Statistics Press.

.2020b. 中國統計年鑑 (Zhongguo tongji nianjian, China Statistical Yearbook). Beijing: China Statistics Press.

ONG, Lynette H. 2014. "State-Led Urbanization in China: Skyscrapers, Land Revenue and 'Concentrated Villages'." The China Quarterly 217: 162-79.

PENG, Sen 彭森 (ed.). 2019. 中國改革年鑑 (Zhongguo gaige nianjian, China Reform Yearbook). Beijing: Compiling Committee for the China Reform Yearbook.

SAMUELS, Warren J. 2004. "Markets and Their Social Construction." Social Research 71(2): 357-70.

SARGESON, Sally. 2016. "The Demise of China's Peasantry as a Class." The Asia-Pacific Journal 14(13): 1-22. 
SCHNEIDER, Mindi. 2015. "What, Then, is a Chinese Peasant? Nongmin Discourses and Agroindustrialization in Contemporary China." Agriculture and Human Values 32(2): 331-46.

2016. "Dragon Head Enterprises and the State of Agribusiness in China." Journal of Agrarian Change 17(1): 3-21.

2017. "Wasting the Rural: Meat, Manure, and the Politics of Agro-Industrialization in Contemporary China." Geoforum 78: 89-97.

State Council 國務院. 2016. “全國農業現代化規劃 (2016-2020年) 的通知" (Quanguo nongye xiandaihua guihua (2016-2020 nian) de tongzhi, Notice on the National Plan for Agricultural Modernisation (2016-2020)).

TRAPPEL, René. 2016. China's Agrarian Transition: Peasants, Property, and Politics. Lanham: Lexington Books.

UNGER, Jonathan. 2002. The Transformation of Rural China. Armonk: M.E. Sharpe.

VAN DER PLOEG, Jan Douwe. 2010. "The Peasantries of the TwentyFirst Century: The Commoditisation Debate Revisited." Journal of Peasant Studies 37(1): 1-30.

VAN DER PLOEG, Jan Douwe, and jingzhong YE. 2016. "The Conundrum of Chinese Agriculture." In Jan Douwe VAN DER PLOEG, and jingzhong YE (eds.), China's Peasant Agriculture and Rural Society: Changing Paradigms of Farming. London: Routledge. 1-24.

VANDERGEEST, Peter. 2003. "Land to Some Tillers: Developmentinduced Displacement in Laos." International Social Science Journal 55(175): 47-56.

WU, Jieh-min. 2010. "Rural Migrant Workers and China's Differential Citizenship: A Comparative Institutional Analysis." In Martin K. WHYTE (ed.), One Country, Two Societies: Rural-Urban Inequality in Contemporary China. Cambridge: Harvard University Press. 55-81.
YAN, Hairong, and Yiyuan CHEN. 2013. "Debating the Rural Cooperative Movement in China, the Past and the Present." Journal of Peasant Studies 40(6): 955-81.

2015. "Agrarian Capitalization without Capitalism? Capitalist Dynamics from Above and Below in China." Journal of Agrarian Change 15(3): 366-91.

YE, Jingzhong. 2015. "Land Transfer and the Pursuit of Agricultural Modernisation in China." Journal of Agrarian Change 15(3): 314-37.

YEP, Ray. 2020. "Local Alliances in Rural Urbanization: Land Transfer in Contemporary China." China Information 34(2): 168-86.

ZHAN, Shaohua. 2017. "Hukou Reform and Land Politics in China: Rise of a Tripartite Alliance." The China Journal 78: 25-49.

ZHANG, Qian Forrest. 2015. "Class Differentiation in Rural China: Dynamics of Accumulation, Commodification and State Intervention." Journal of Agrarian Change 15(3): 338-65.

ZHANG, Qian Forrest, and John A. DONALDSON. 2008. "The Rise of Agrarian Capitalism with Chinese Characteristics: Agricultural Modernization, Agribusiness and Collective Land Rights." The China Journal 60: 25-47.

2010. "From Peasants to Farmers: Peasant Differentiation, Labor Regimes, and Land-rights Institutions in China's Agrarian Transition." Politics \& Society 38(4): 458-89.

2013. "China's Agrarian Reform and the Privatization of Land: A Contrarian View." Journal of Contemporary China 22(80): 255-72.

ZHANG, Qian Forrest, Carlos OYA, and Jingzhong YE. 2015. "Bringing Agriculture Back In: The Central Place of Agrarian Change in Rural China Studies." Journal of Agrarian Change 15(3): 299-313. 